\title{
Borgerinddragelse som opdragelse til repræsentativt demokrati
}

\author{
Michael Böss
}

Institut for Æstetik og Kommunikation, Aarhus Universitet

Bør vi se den faldende tillid til politikere og flugten fra de konventionelle partier som en systemisk krise i det repræsentative demokrati eller blot som et resultat af manglende forventningsafstemning mellem politikere og vælgere? I denne artikel argumenterer lektor Michael Böss for sidstnævnte og leverer hermed et både teoretisk og empirisk forsvar for det repræsentative demokrati. Dog fremhæves det afslutningsvist, at deliberative processer på lokalpolitisk plan kan styrke demokratiet og „opdrage“ borgerne til at udnytte mulighederne i det repræsentative demokrati til fulde.

Det overordnede formål med denne artikel er at forsvare det repræsentative demokrati. Artiklen er kritisk over for påstanden om, at den nuværende mistillid til politikere og den faldende politiske deltagelse skal ses som udtryk for en krise for det repræsentative demokrati som sådan. Jeg argumenterer - på klassisk vis - for, at det afhænger af en høj grad af politisk deltagelse og en oplyst offentlighed, som tilkender det legitimitet og har tillid til dets effektivitet. Min tese er, at borgernes inddragelse i deliberative processer bør forstås i lyset af den tradition for deltagerdemokrati, som har været praktiseret i Danmark og de øvrige skandinaviske lande efter anden verdenskrig ud fra den opfattelse, at det repræsentative demokrati forudsætter en levende demokratisk kultur. Jeg konkluderer derfor, at borgerinddragelse kan styrke den demokratiske kultur og give borgerne forståelse for det repræsentative demokratis karakter, formål og betingelser.

Artiklen er bygget op i fire afsnit, foruden indledning og konklusion. I det første afsnit konstaterer jeg, at det repræsentative demokrati siden anden verdenskrig har været anset for normen for demokrati globalt set, fordi det betragtes som en både legitim og effektiv styreform. Jeg konstaterer dog samtidig, at der i de seneste årtier nationalt og internationalt har været en debat, som har været kritisk over for det repræsentative demokratis tilstand. I det andet afsnit viser jeg, hvordan direkte og deliberativt demokrati i dag anses som måder til fornyelse af demokratiet. Artiklens tredje afsnit forklarer, hvorfor de ikke bør anses som alternativer, men som supplementer til det repræsentative demokrati, dels med henvisning til undersøgelser, der viser, at man ikke bør gøre sig urealistiske forventninger om større demokratisk deltagelse fra borgernes side, dels med en argumentation for, hvorfor borgernes større mistillid til politikerne ikke kan tolkes som en mistillid til det repræsentative demokrati som sådan. I det fjerde, diskuterende, afsnit foreslår jeg, at det er en god idé at inddrage borgerne i tidsbegrænsede, deliberative processer i nærdemokratiet, fordi det vil kunne styrke både den demokratiske kultur og forståelsen af det repræsentative demokrati. I min konklusion fastslår jeg derfor, at borgerinddragelse bør ses som et værdifuldt supplement, men ikke et alternativ, til det repræsentative demokrati.

\section{Kritikken af det repræsentative demokratis tilstand}

Alle væsentlige internationale konventioner har siden afslutningen af anden verdenskrig set det repræsentative demokrati som normen for demokrati. ${ }^{1}$ Men det betyder ikke, at borgerens „direkte“, dvs. aktive, deltagelse i de demokratiske processer, dermed er udelukket. I paragraf 21 af FN's Menneskerettighedserklæring fra 1948 hedder det f.eks., at „enhver [borger] har ret til at deltage i sit lands styre, direkte eller gennem deres frit valgte reprasentanter" 
(Universal Declaration, min kursivering). Formuleringen går igen i paragraf 25 af Den Internationale Konvention om Civile og Politiske rettigheder fra 1966/1976.

Selvom afholdelse af frie og regelmæssige valg bliver anset for en betingelse for demokrati, fremstilles det repræsentative demokrati dog ikke snævert som et rent proceduralt system baseret på flertalsstyre og valg. OAS’s Inter-american Democratic Charter (2001) fastslår således, at demokrati er et politisk system, der ikke kun skal sikre udøvelse af folkelig suverænitet; det skal også sikre respekt for befolkningens menneskerettigheder og borgernes fundamentale frihedsrettigheder, foruden ,adgang til og udøvelse af magt i overensstemmelse med the rule of law" (OAS Inter-american Charter, paragraf 3). I alle dokumenter siden anden verdenskrig forudsættes det $\mathrm{dog}$, at borgernes aktive deltagelse først og fremmest skal foregå inden for politiske partier og organisationer og selve valghandlingen. Resten er overladt til deres valgte repræsentanter.

Den klassiske begrundelse er, at i moderne storskalademokratier - eller "polyarkiske demokratier" - er den eneste mulige styreform et system, hvor borgerne vælger „deres ledere og gør dem mere eller mindre ansvarlige gennem valg ved så at sige afskedige dem ved efterfølgende valg"(Dahl 2000, 93). Begrundelsen bygger på en erkendelse af, at den demokratiske deltagelse må begrænses af praktiske hensyn, dels den numeriske størrelse af det politiske fællesskab, dels hensynet til effektivitet. Som John Stuart Mill skrev i 1861: „Men da ikke alle $i$ et samfund, der er større end en enkelt lille by, kan deltage personligt i mere end nogle mindre dele af den offentlige styring, så følger det, at idealtypen af en perfekt regeringsform må være repræsentativt" (Mill 1958, 55). Forsvaret for det repræsentative demokrati udelukker dog ikke andre former for folkelig deltagelse i politiske beslutningsprocesser. Sådan har det da også vist sig i praksis. Selv i stater med „parlamentarisk suverænitet" - dvs. lande, der har eller har overtaget den såkaldte Westminster-model - afholdes der i dag folkeafstemninger, og i andre demokratier, specielt de skandinaviske, har der været praktiseret"deltagerdemokrati “ $i$ større eller mindre omfang, dels i form af folkeafstemninger, dels i form af borgernes inddragelse i forskellige former for nærdemokrati.

Man har i de senere år hørt argumenter for, at der er behov for mere demokratisk deltagelse i dag. Som det fremgår af dette temanummer, hersker der nemlig både nationalt og internationalt i disse år betydelig bekymring for det repræsentative demokratis fremtid. Fra visse hold hævdes det ligefrem, at det ikke fungerer tilfredsstillende i sin nuværende form og derfor må erstattes af nye demokratiske strukturer og institutioner.
En af de indikatorer, der peges på, er faldende valgdeltagelse. På baggrund af sin dokumentation af faldende valgdeltagelse i europæiske og nordamerikanske demokratier, skriver f.eks. den anerkendte britiske journalist og forfatter Philip Coggan, at nutidens vælgere er „desillusionerede", og at dette er et demokratisk problem, som man ikke bør ignorere. For „, $[\mathrm{r}]$ ationalet bag det repræsentative demokrati er, at vælgerne skal vælge de personer, som laver de love, de styres af [...] Hvis deltagelsen i valgprocessen hele tiden er på vej ned, så vil regeringens legitimitet begynde at lide under det" (Coggan 2013, 40). Hvis den folkelige deltagelse mindskes, vil demokratiet fremover blive et system, der udelukkende varetages af små, udvalgte grupper, advarede en $\mathrm{FN}$-rapport allerede om for ti år siden. Så vil politiske beslutninger ikke længere „blive gjort til genstand for offentlig kontrol og forhandling", to af demokratiets "kerneværdier“ (UN 2004).

En anden indikator, der ofte bliver brugt, er borgernes tillid til politikerne, de nationale parlamenter og deres regeringer. I 2012 konstaterede Eurobarometer således, at tilliden til de nationale parlamenter og regeringer lå på henholdsvis 28 og 27 procent (Eurobarometer 78, 2012). Endnu værre ser det ud for tilliden til de politiske partier (Eurofoundation 2012).

På begge sider af Atlanten blev der i begyndelsen af 00 'erne sat undersøgelser og kommissionsarbejder i gang med det formål at stille forslag til, hvordan demokratiet kunne fornys og tilføres mere energi. (Rowntree 2006; Carnegie 2008). I Norge hævdede et af bindene i Maktog demokratiutredningen i 2003, at det repræsentative demokrati som styreform gennem folkevalgte organer og parlamentariske principper var under svækkelse og „i tilbagegang" (Østerud, Engelstad og Selle 2003, 57). Det skyldtes, at de folkevalgte organer i mindre grad end tidligere var i stand til at kontrollere de faktorer, som afgjorde befolkningens levevilkår. De var ved at miste evnen til at sikre en samordnet og effektiv samfundsstyring og fordeling af goder og byrder. I stedet blev myndigheden overført til multinationale koncerner, forskellige markedsaktører, uafhængige forvaltningsorganer samt nationale og overnationale retslige institutioner.

Den danske magtudredning var mere fortrøstningsfuld. Den konstaterede, at demokratiet havde forstået at tilpasse sig de ændrede vilkår, og at der fortsat syntes at være demokratisk livskraft i den danske befolkning. Udredningen konkluderede på den baggrund, at det repræsentative demokrati ikke var i krise, men blot under forandring (Andersen 2004). Dog konstaterede dens forfattere, at selv om „danskernes politiske engagement ikke fejler noget", så er der en tendens til, at det politiske engagement retter sig mod landspolitikken frem for den lokale politik, ligesom aldersgruppen under 50 har en 
„bekymrende“ lille interesse for politik over det nationale niveau (Andersen 2004, 57).

Den optimistiske tone i den danske magtudrednings konklusion om, at ,[i]ntet tyder på, at den politiske deltagelse alt i alt er faldet gennem de seneste årtier" (Andersen 2004, 223), står i skærende kontrast til en række analyser af det danske samfunds og folkestyres tilstand inden for den sidste halve snes år. I Den politiske blender (2004) påpegede eksempelvis Johannes Andersen, at der er en sammenhæng mellem eroderingen af deltagerdemokratiet og den individualisering, der sker i markedssamfundet. I det moderne, liberale samfund reduceres demokratiet til selve det at vælge (Andersen 2004, 30). Tim Knudsen brugte Hal Kochs idealer om dialog og deltagelse i sin egen vurdering af nutidens "markedsdemokrati“ (Knudsen 2007). Knudsen mente, at vi er på vej mod et samfund, der vil være opdelt mellem en elite af konkurrerende professionelle politikudbydere og en masse passive demokratibrugere. I et sådant samfund bliver demokrati til et spørgsmål om politisk effektivitet. I Konkurrencestaten (2011) kædede Ove K. Pedersen udviklingen sammen med velfærdsstatens afløsning af „konkurrencestaten“. Globaliseringen har fremkaldt en fælles forståelse i de nationale eliter for nødvendigheden af at kontrollere de vitale dele af statsbureaukratiet og det politiske system. Det gør det uhensigtsmæssigt at inddrage borgerne i noget videre omfang, idet de derved ville kunne obstruere en strategi, som har til formål at øge statens økonomiske konkurrenceevne og overlevelseskraft (Pedersen 2011, kap. 5). Endelig påviste Lars Bo Kaspersen med en beslægtet argumentation i Danmark $i$ Verden, at de politiske og økonomiske eliter tolker de internationale forandringsprocesser som et pres, der "dikterer nødvendige reformer“, der har til formål at opruste befolkningen, de offentlige institutioner og virksomhederne; dog ikke gennem øget demokratisering, men ved at øge magtkoncentrationen i statsapparatet og centraladministrationen. Hvor staten tidligere gennemførte reformer efter først at have været i forhandling og dialog med samfundets aktører og interessegrupper, gennemfører den dem i dag uden forudgående konsultationer (Kaspersen 2008, 218, 219).

De fire danske kritikere konstaterede altså, at det danske demokrati har bevæget sig fra et ideal om demokratisk deltagelse til en praksis, som indebærer større centralisering, større magt til de politiske og bureaukratiske eliter og en afkobling af vælgerne og det civile samfunds institutioner og organisationer fra de politiske beslutningsprocesser. Alle er de enige om, at det direkte eller indirekte skyldes presset fra „markedet“, specielt det globale. Men indbyrdes er de ikke enige om at vurdere demokratiets "effektivisering" som god eller dårlig for det repræsentative demokratis legitimitet.
Både nationalt og internationalt har mange kritikere af udviklingen dog næret den opfattelse, at en løsning på det repræsentative demokratis problemer måtte være større borgerdeltagelse. Og det på trods af, at vælgerne i de sidste to-tre årtier har trukket sig tilbage fra aktiv politisk deltagelse. I Danmark gælder dette ganske vist ikke folketingsvalg, men til gengæld ser man det både inden for kommunalvalg og valg til EU-Parlamentet. Specielt mærkbar er tendensen blandt unge og etniske minoriteter. Efter "klassepolitikkens forsvinden“ (Andersen m.fl. 2007; Green-Pedersen 2011) er det desuden gået støt tilbage for borgernes medlemskab af partiforeninger (Bille 2003), og selv de, der endnu er medlemmer, er langt mindre engagerede end tidligere. En undersøgelse foretaget blandt partimedlemmer i 2012 viser, at cirka halvdelen af medlemmerne ikke deltager i deres partis aktiviteter; at kun få tager kontakt til deres folkevalgte for at få indflydelse; at op mod en sjettedel af medlemmerne slet ikke diskuterer partiets politik med familie, venner eller arbejdskolleger; at kun mellem 6 og 14 procent af partiernes medlemmer er villige til at stille op til byrådet for deres parti, mens det gælder for mellem 8 og 24 procent til folketingsvalg; og at blot en tredjedel deltager i opstillingsmøder eller afstemninger, da der skulle vælges kredskandidater til folketingsvalget i 2011 (KosiaraPedersen og Møller Hansen 2012).

I den internationale litteratur er der dog siden slutningen af 1990'erne imidlertid argumenteret for, at faldende politiske deltagelse ikke nødvendigvis bør ses som en mistillidserklæring til demokratiet, men snarere til politikerne og til den måde, det bliver forvaltet på af dem (Norris 1999 og 2001; Dalton 2004). I forbindelse med kampagnen for unges deltagelse i kommunalvalget i 2013 hørte man det ligeledes hævdet, at unges manglende deltagelse - ved enten at blive hjemme eller stemme blankt i virkeligheden var udtryk for en høj grad af demokratisk bevidsthed. Som en studerende på CBS udtalte sig til netavisen Modkraft: „Hver gang vi stemmer, udøver vi vores demokratiske ret, hedder det. Det er dog lige præcis paroler som denne, der efterhånden har sendt det moderne demokrati til tælling. For et sundt demokrati indebærer helt utroligt meget mere end blot at sætte sit kryds ud fra et bogstav med et par års mellemrum“. Ved ikke at stemme var man „med til at kræve en debat om den passiviserende praksis, vores lokale demokrati efterhånden har udviklet sig til" (Husted 2013). Og journalisten, idéhistorikeren og samfundsdebattøren Rune Lykkeberg skrev i et indlæg i Politiken, at lav valgdeltagelse godt kunne ses som et udtryk for, at „nogle eller noget ikke bliver repræsenteret af de politiske partier og ikke kan se meningen med kommunerne. Det kunne være et kritisk feedback" (Lykkeberg 2013). 
Det er utvivlsomt vigtigt ikke at forveksle mistillid til politikere og regeringer med mistillid til demokratiet som sådan; heller ikke til det repræsentative demokrati. På den anden side vil et faldende aktivt engagement og en generel politikerlede på længere sigt kunne udvikle sig til en svækkelse af den demokratiske kultur og en manglende støtte til det repræsentative demokrati som styreform. Betyder det, at der er brug for at overveje alternative modeller?

\section{Direkte og deliberativt demokrati}

I juli 2008 slog professor Peter Kurrild-Klitgaard i en artikel i Berlingske til lyd for en udvidelse af „folkets vetoret“ (Kurrild-Klitgaard 2008). Han konstaterede, at Folketinget efterhånden har „overtaget den rolle og magt, som fortidens enevældige konger havde“. Han begrundede forslaget med, at folkeafstemninger er en styrkelse af borgernes muligheder for at holde de folkevalgte i skak. Men man kunne komme den glidende magtkoncentration, der havde fundet sted, til livs, ved at give vælgerne bedre mulighed for at deltage i demokratiet. Man kunne f.eks. afholde flere folkeafstemninger, hvor de kunne „give deres besyv med, enten ved selv at sætte spørgsmål på den politiske dagsorden, som politikerne har forsømt, eller ved at bruge muligheden for evt. at nedlægge veto mod politikernes beslutninger“. Kurrild-Klitgaard henviste til samfundsforskere, der har studeret brugen af folkeafstemninger internationalt.

Mads Qvortrup er en af dem (Qvortrup 2006 og 2010). Qvortrup opregner således en række positive sociale og politiske konsekvenser. Han er klar over, at direkte demokrati ikke kan levere en universalløsning på alle det repræsentative demokratis problemer. Alligevel mener han, at der er empirisk belæg for at hævde, at samfund, hvor borgerne deltager aktivt i de politiske processer, er bedre regeret, er rigere og lider under færre sociale onder end andre samfund. Desuden er der en positiv implikation ved direkte demokrati, nemlig at det gør vælgerne mere „ansvarlige“ og mindre tilbøjelige til at give politikerne skylden for alle plager.

Argumentet for direkte demokrati bygger på en række antagelser, først og fremmest troen på, at blot de bliver tilstrækkeligt oplyst og informerede, så er almindelige borgere i stand til at træffe rationelle beslutninger for sig selv og deres medborgere. De er også indstillede på at tilsidesætte egeninteresser til fordel for helheden. Tilhængerne af direkte demokrati forudser, at der fortsat vil findes politiske partier. Men betydningen af dem vil være mindre. Desuden vil tendensen til professionalisering af politikerrollen aftage. Endelig vil der ske en kvalitetsforhøjelse af de politiske beslutninger (Hansen 2010, 109-23; Budge 1996).
Tilhængere af deliberativt demokrati er skeptiske over for den „populisme“ og det „stemningsdemokrati“, som direkte demokrati vil kunne medføre. De mener, at de deliberationer, borgerne skal foretage med hinanden, skal foregå inden for tilfældigt udvalgte grupper af borgere, som på grundlag af eksperthøringer og indbyrdes, rationel argumentation skal søge at opnå størst mulig enighed, ja, helst konsensus. De mest fremtrædende fortalere for deliberativt demokrati (f.eks. Elster 1988; Goodin 2008; Fishkin 1998) ser det dog ikke som en erstatning, men som et supplement til det repræsentative demokrati. De mener, at den afsluttende debat skal henlægges til den lovgivende forsamling og danne grundlag for en afstemning.

I visse af de forsøg med deliberativt demokrati, der er blevet gennemført gennem de sidste par årtier, har den lovgivende forsamling valgt at kombinere deliberativt og direkte demokrati, dvs. ladet en deliberativ proces afslutte med en folkeafstemning. Det gælder f.eks. det forsøg, der blev gennemført i British Columbia i Canada i begyndelsen af dette årtusinde, om indførelsen af et nyt valgsystem (Warren og Pearse 2008). Eksperimentet viste, at borgerne rent faktisk evnede at tage stilling til selv komplicerede spørgsmål. Men det skuffede på et afgørende punkt: Det førte nemlig ikke til øget valgdeltagelse, idet forsamlingens forslag blev forkastet ved den efterfølgende folkeafstemning. Desuden viste det sig, at en stor del af vælgerne slet ikke havde fulgt med i den deliberative borgerforsamlings arbejde, ja, at de end ikke havde hørt om det. Mange vælgere havde heller ikke i forvejen sat sig ind $i$, hvad forsamlingens anbefalede reform af valgsystemet ville indebære.

En forklaring på, at forsamlingen i British Columbia ikke fik tilstrækkelig offentlig opmærksomhed, er måske også, at Canada styres efter den såkaldte Westminstermodel, som med sit dogme om parlamentarisk suverænitet ikke opmuntrer borgerne til demokratisk deltagelse uden for valgene. Man kunne således antage, at deliberativt demokrati ville kunne fungere, hvor der i forvejen findes en deltagerdemokratisk tradition. Det gør der i Danmark, og Danmark er faktisk det land i verden, der først begyndte at praktisere det. Det skete efter en model udviklet af det daværende Teknologirådet på et tidspunkt, hvor vi stod over for planer om indførelse af ny teknologi på arbejdspladserne og i samfundet generelt.

Man bør dog ikke deraf konkludere, at modellen kan bruges i en dansk sammenhæng som et alternativ til det repræsentative demokrati. Og specielt må man advare mod at tro, at der tale om en form for politisk deltagelse, som borgerne er indstillet på at investere mange kræfter i. Der er nemlig klare indikationer på, at der er grænser for, hvor megen aktiv deltagelse, man kan forvente af dem. 


\section{Grænser for borgernes politiske engagement og forståelse}

Selv om der blandt vælgere i Danmark i disse år hersker en historisk lav tillid til politikerne, så forekommer det dog langt fra at være det repræsentative demokrati som sådan, de nærer mistillid til. Der har da heller ikke været målt faldende tilslutning til demokratiet som sådan (Svensson 2011), og selv om tilfredsheden med den måde, demokratiet fungerer på, er faldet i de seneste fem år - til 88 procent af de adspurgte - så ligger denne andel langt over de blot 66 procent, der var tilfredse under krisen i begyndelsen af 1980'erne (Stubager m.fl. 2013, 57). En lignende støtte til demokratiet gør sig gældende i Norge, et land som vi med stor rimelighed kan sammenligne os med (Strømsnes 2003), og som derfor kan bruges som kilde til forståelse af skandinaviske holdninger til politisk deltagelse.

På internationale skalaer ligger skandinavernes politiske interesse højt. Når nordmænd og svenskere bliver spurgt, hvor vigtigt politik er for deres liv, så svarer dog kun ca. 10 procent af de første og 15 procent af de sidste "meget vigtigt", mens ca. 48 procent af dem begge svarer „ret vigtigt“. Hele 40 procent svarer, at politik er „ikke meget vigtigt" eller "overhovedet ikke vigtigt" (World Values Survey 2005-2008). ${ }^{2}$ På den baggrund bør man ikke gøre sig urealistiske forventninger om større aktiv deltagelse fra borgernes side i fremtiden.

Norske undersøgelser viser, at der som hovedmønster er betydelig tilfredshed med egen demokratisk deltagelse, men ikke noget ønske om at øge den. Mange kan tilsyneladende godt opleve sig som aktive medborgere uden at være medlemmer af et politisk parti, en organisation eller en forening. Godt og aktivt medborgerskab kan forstås som blot det at have en selvstændig mening, at stemme ved valg, at leve efter sit lands love og regler, at være solidarisk over for andre og at tage hensyn. Folk interesserer sig rigtignok for politik, men de gør det kun i moderat omfang. De prioriterer familie, venner, fritid og arbejde højere. Mange opfatter desuden politik for så indviklet, at de hellere end gerne overlade den til andre med den fornødne viden og kompetence. Andre afstår fra at engagere sig aktivt i politik, fordi det er tids- og arbejdskrævende. Mange er indstillede på at deltage, men kun hvis det drejer sig om at tage stilling til specifikke og tidsafgrænsede projekter. For flertallet synes demokratiet mere at være et spørgsmål om at blive taget hensyn til end selv at deltage (Olsen 2014, 179-87).

Som led i det såkaldte Projekt Hverdagsdemokrati bad Københavns Kommune i efteråret 2002 politologen Roger Buch Jensen om at undersøge 1000 københavneres syn på deres kommune og demokratiet. 68 procent af dem mente, at Borgerrepræsentationens indflydelse på politikken i kommunen var passende. 53 procent mente, at borgerne som helhed havde en passende indflydelse. 80 procent af de adspurgte udtrykte tilfredshed med demokratiet som helhed i kommunen. Der var med andre ord tilfredshed med den måde, det repræsentative demokrati fungerede på. Det betød dog ikke, at borgerne ikke gerne så sig yderligere inddraget i de demokratiske beslutningsprocesser. Det skulle blot ske inden for tidsmæssigt begrænsede perioder. De ønskede ikke at være aktive medborgere i den betydning, at de skulle være politisk aktive hele tiden og erstatte de folkevalgte (Københavns Kommune 2003). For en stærk tilhænger af "aktivt demokratisk medborgerskab" kan dette resultat nok forekomme nedslående og ses som et tegn på en tynd demokratisk kultur. Man bør dog snarere se det som et demokratisk sundhedstegn. For det kan også tolkes som udtryk for befolkningens tillid til, at dets repræsentative politiske aktører - til trods for al deres tendens til mudderkastning og indbyrdes rivalisering - alligevel gør deres arbejde rimeligt godt. Og i hvert fald bedre, end man selv ville være i stand til eller være parat til at afsætte tid og kræfter til.

Hvordan harmonerer det med den empirisk målte stigende mistillid til politikerne i de senere år? Før man drager for vidtgående slutninger ud fra de senere års målinger af voksende mistillid til politikere, bør man dog tage højde for visse kendsgerninger. Der er således for Danmarks vedkommende ikke tale om noget længerevarende fænomen, men derimod om en tendens, som først har vist sig $i$ årene efter den finansielle og økonomiske krise i 2008. Mange vælgere har ganske givet oplevet krisen som resultatet af politikersvigt, sådan som de gjorde det i mange andre europæiske lande, f.eks. i Irland. Under den efterfølgende recession herskede der givetvis også bekymring om, hvorvidt de folkevalgte evnede at løse problemerne. Endelig har den såkaldte løftebrudspolitik under Thorning-regeringen 2011-2015 højst sandsynlig bidraget til mistilliden (Stubager m.fl. 2013, 57; Altinget 2014). Krisen fik vælgerne til at betvivle politikernes evne til at levere resultater, og de såkaldte løfter skabte et forventningsniveau, som regeringen ikke var i stand til at imødekomme, ja, tilmed skuffede, da Socialdemokraterne blev presset af De Radikale til tværtimod at indføre velfærdsstramninger og anden „nødvendig politik“. Lignende forhold har gjort sig gældende i andre europæiske demokratier, hvor den politiske tillid er faldet.

Mistillid til politikere bør således bl.a. forstås som et mål på forholdet mellem vælgerforventninger og politikerpræstationer. I alle demokratier er der indbygget spændinger mellem borgernes forventninger og politikernes muligheder for at levere, og de historiske erfaringer viser, at sådanne spændinger har en tendens til at øges i pe- 
rioder med lavkonjunktur og reformer. I en sund demokratisk kultur fører den forbigående mistillid ikke til en mistillid til det demokratiske system som sådan. Som jeg tidligere var inde på, så kan afstanden mellem vælgernes forventninger og politikernes evne til at levere dog også blive så stor, at „kritiske vælgere“ også mister tilliden til det politiske system. Oplevelsen af stigende „demokratisk underskud“ kan - i kombination med faldende politisk performans og generelt lave vurderinger af de folkevalgtes kompetencer og moralske habitus - på den måde få alvorlige konsekvenser for den politiske deltagelse, den politiske adfærd, respekten for landets love og demokratiet som sådan (Norris 2011, 8).

Det forekommer dog ikke rimeligt at lægge al skylden for denne udvikling på politikerne. I stedet bør man se den som en følge af udviklingen „fra folkestyre til markedsdemokrati“, som Tim Knudsen kalder den (Knudsen 2007). Hvis vælgerne betragter deres politikere som leverandører af varer til deres eget forbrug - og anser forholdet mellem dem selv og deres partier som et kontraktforhold - så vil deres forventninger naturligvis lettere kunne skuffes, end hvis de ser dem som repræsentanter, der har ansvar for også at tage hensyn til hele samfundet. I det sidste tilfælde vil forståelsen af nødvendigheden af reformer, der rent umiddelbart forekommer dem at gå imod deres personlige interesser, være lav. Det er derfor, at et politisk oplyst vælgerkorps traditionelt har været betragtet som en nødvendig forudsætning for et oplyst demokrati (Møller Hansen 2007). Jeg vil på den baggrund foreslå, at se det repræsentative demokratis påståede krise som en krise $\mathrm{i}$ offentligheden for forståelsen af folkestyrets idé og vilkår. I det omfang, det danske folkestyre kan siges at være i krise, skyldes det således ikke kun, at visse politikere er begyndt at betragte vælgerne som kunder, men også at den demokratiske kultur er svækket.

Hvis det repræsentative demokrati skal kunne fungere, er det nødvendigt, at borgerne forstår demokratiets grundvilkår og mål. Denne forståelse har vi i Danmark traditionelt givet folkeskolen ansvar for at opbygge. Men lige så vigtigt for den demokratiske kultur var det tidligere, at en langt større del af vælgerkorpset var medlemmer af en vælgerforening og et parti. I dag er procentdelen svundet betragteligt ind. Samtidig bliver demokratisk dannelse ikke længere betragtet som en hovedopgave i en folkeskole, som i stedet mere og mere anses som en forgård til arbejdsmarkedet. Det øger behovet for nye institutioner, hvor unge og voksne kan dannes til demokratiske medborgere. Selv om de ikke kan stå alene om opgaven, vil deliberative forsamlinger og andre former for borgerinddragelse kunne medvirke til at styrke den forståelse for demokratiet, som går tabt i ,markedsdemokratiets“ og „konkurrencestatens“ tidsalder.

\section{Demokrati og globalisering}

I bogen DeltagerDanmark hævdede en række yngre socialdemokrater for et par år siden for, at der var brug for en "grundlæggende demokratisering" af det danske samfund. De mente, at det måtte være «det politiske centrum-venstres opgave at engagere tusindvis af danskere i arbejdet for at opfylde en ny politisk mission [...] som handler om, at vi som borgere genvinder magten over vores egne liv - over vores arbejde, vores penge, vores partier, vores bevægelser og vores velfærd» (Hansen m.fl. 2013, 14 og omslag). Forfatterne forudsagde forhåbningsfuldt, at det 21. århundrede ville blive "deltagernes århundrede», og de satte sig som mål at bidrage til «at skabe et samfund, hvor ingen små grupper eller klasser af f.eks. finansfyrster, bureaukrater eller spindoktorer alene kan definere samfundsudviklingen" (Hansen m.fl. 2013, 15). De anså demokratisk selvmobilisering for at være en historisk tradition, der gik tilbage til 1800-tallets folkelige bevægelser. Også i dag skulle fornyelsen komme fra civilsamfundet. Selv om de i et afsnit om Island udtrykte sympati for brugen af folkeafstemninger som et middel til en folkelig generobring af samfundsmagten, opfordrede forfatterne dog ikke til at indføre hverken direkte eller deliberativt demokrati på bekostning af det repræsentative. Deltagelse betød i stedet, at borgerne skulle blive bedre til at bruge de eksisterende politiske institutioner (Hansen m.fl. 2013, 42, 44).

Oplægget til en „demokratisering fra neden“ havde en klar kritisk brod imod den „effektivisering“, som dele af den politiske elite i dag anser for at være en bedre måde at imødekomme vælgernes behov. Den blev da heller ikke mødt med begejstring fra forfatternes eget parti. Da tænketanken CEVEA's i sit nettidsskrift Magasinet Politik bad den senere erhvervs- og vækstminister Henrik Sass Larsen om at forholde sig til bogens budskab, svarede han, at folk i dag ikke ønskede mere demokrati, men større effektivitet: „Folk ønsker, at tingene skal fungere effektivt. Det giver ikke nogen mening, at folk skal blive ved med at gå til beboermøder, hvis der ikke er nogen grund til at gå til beboermøde. Hvis forholdene er velfungerende, hvorfor skal man så sidde til møder bare, fordi man bor det samme sted?“ Sass Larsen fandt „den nye demokratiseringsbølge“ overdreven: „Det er som at være ung igen at se den fokus på demokratisering. Det er et politisk projekt, jeg absolut ikke kan anbefale“ (Magasinet Politik 2013).

De to positioner, som debatten om bogen afspejlede, kan ses som udtryk for to forskellige måder at forholde sig til globaliseringens udfordringer. Ifølge den første holdning kræver globaliseringen en uddybning og fornyelse af et demokrati, som trues af delegitimisering. Ifølge den anden kræver den en centralisering af den politiske 
magt af hensyn til effektivitet (f.eks. Münckler 2011). Det kan således lyde, som om de to klassiske argumenter for det repræsentative demokrati - legitimitet og effektivitet - i dag er kommet i et indbyrdes modsætningsforhold. Udfordringen til det repræsentative demokrati må derfor være at fungere på både en legitim og effektiv måde. Men der er også en vigtig opgave for borgerne: at forstå demokratiets mål og vilkår.

Hal Koch havde utvivlsomt ret, når han hævdede, at folkestyret kun ville blive anset for legitimt, hvis det procedurale demokrati blev kombineret med borgernes aktive deltagelse ud over valgene. Dette krævede, at der fandtes en levende demokratisk kultur. Den aktive deltagelse skulle komme til udtryk i „det lille demokrati“, dvs. nærdemokratiet, men han mente, det burde føres endnu videre, som f.eks. økonomisk demokrati. Hvad den demokratiske kultur - demokrati som livsform - angik, anså han det for afgørende, at borgerne forstod, at hensynet til fællesskabets og helhedens vel var en afgørende faktor for et velfungerende demokrati.

Denne "republikanistiske“ forståelse af demokratiet er afgørende, fordi den indebærer, at borgerne skal være parate til at acceptere politiske nederlag, kompromiser og således til at tilpasse deres forventningsniveau til det politiske systems præstationsniveau. For Koch var denne demokratiforståelse noget, man skulle opdrages og dannes til. Og hvis den ikke fandtes, så ville det i sidste instans gå ud over „det store demokrati“, dvs. det repræsentative demokrati. Det repræsentative demokrati forudsatte altså både folkelig deltagelse og demokratisk oplysning for at kunne fungere legitimt og effektivt.

Disse tanker blev i vidt omfang ført ud i livet i efterkrigstiden og kom til at præge den forståelse af demokratiet, som herskede inden for partiernes vælgerforeninger. Derved blev det danske samfund præget af en bred forståelse af værdien af at kunne forhandle sig frem til løsninger, som det store flertal kunne acceptere, i stedet for at gennemtrumfe ideelle løsninger. Denne konsensustradition har givetvis haft en konfliktdæmpende virkning og skabt stabilitet i samfundet. Men vil denne tradition kunne overleve nutidens vælgeres „tilbagetrækning“ fra aktiv politik, svigtende demokratisk dannelse i skolen og voksende mistillid til politikere, etablerede partier og regeringer?

\section{Konklusion}

De nordiske lande har hidtil vist sig at kunne bevare deres særlige samfundsmodel og undgå den slags sociale splittelser og politiske konfrontationer mellem højre og venstre, som har præget andre lande i Europa. Dette må i høj grad tilskrives den måde, deres repræsentative demokratier har udviklet sig og tilpasset sig på under nye vilkår.
Efter anden verdenskrig skete det gennem en udvidelse af borgernes aktive politiske deltagelse. De skandinaviske demokratier er på den måde blevet funderet på en unik politisk kultur kendetegnet af en sammenhæng mellem det „lille“ og det „store“ demokrati, som er unik i en global sammenhæng (Mayne 2010).

Man kan spørge sig selv, om denne særlige demokratiske kultur vil kunne overleve globaliseringen, som lægger så meget pres på de nationale regeringer, at de føler sig tvunget til at centralisere og effektivisere de politiske beslutningsprocesser og derved skruer ned for borgernes aktive deltagelse. Man kan desuden spørge sig selv, hvad det vil betyde for den demokratiske kultur, at medierne vænner vælgerne til at betragte politik som et marked.

Jeg har i denne artikel afvist direkte demokrati og deliberativt demokrati som svar på disse udfordringer og derfor som alternativer til det repræsentative demokrati. Jeg har i stedet argumenteret for nødvendigheden af at bevare det repræsentative demokrati og for ikke at overdrive bekymringerne over demokratiets tilstand. Demokratier er altid løbet ind i kriser, men har altid vist sig gode til at komme sig over dem (Runciman 2013). Samtidig har jeg mindet om, at det i de sidste 60-70 år aldrig har udelukket andre former for politisk deltagelse. $\mathrm{Ja}$, jeg vil endog konkludere, at det i dag er vigtigere end nogensinde at bevare denne tradition, ja, ligefrem at udvide den med deliberative processer af tidsbegrænset varighed. Jeg er skeptisk over for muligheden og ønskværdigheden af at indføre deliberative institutioner på det landspolitiske plan. Til gengæld vil borgerinddragelse på det kommunalpolitiske niveau kunne vise sig værdifuld bl.a. fordi den - lidt paradoksalt udtrykt - vil være gavnligt for styrkelsen af forståelsen i offentligheden for det repræsentative demokratis karakter, betingelser og mål. $\mathrm{Ja}$, i Hal Kochs ånd vil borgerinddragelse kunne fungere som „opdragelse til demokrati“.

\section{Litteratur}

Altinget 2014, 'Tilliden til politikerne styrtdykker', 4. januar, http:// www.altinget.dk/artikel/tilliden-til-politikerne-styrtdykker.

Andersen, J. 2004, Den politiske blender, Aarhus: Hovedland.

Andersen, J.G. 2004, Et ganske levende demokrati, Aarhus: Aarhus Universitetsforlag.

Andersen, J.G. m.f. (red.) 2007, Det nye politiske landskab. Folketingsvalget $i 2005$ i perspektiv, København: Systime Academic.

Budge, I. 1996, The Challenge of Direct Democracy, Cambridge: Cambridge University Press.

Cain, B.E. Cain, R. Dalton og S. Scarrow (red.) 2003, Politics Reformed: Expanding Political Opportunities in Advanced Industrial Democracies, Oxford: Oxford University Press.

Coggan, P. 2013, The Last Vote: The Threats to Western Democracy, London: Allen Lane.

Cronin, T.E. 1989, Direct Democracy: The Politics of Initiative, Referendum, and Recall, Cambridge, Mass.: Harvard University Press. 
Dahl. R.A 2000, On Democracy, New Haven: Yale University Press.

Dalton, R.J. 2004, Democratic Challenges, Democratic Choices, Oxford: Oxford University Press.

DeBardeleben, J. og J.H. Pammet (red.) 2009, Activating the Citizen: Dilemmas of Participation in Europe and Canada. Houndmills: Palgrave Macmillan.

Economist 2009, 'The tyranny of the majority', 19. dec.

Economist Intelligence Unit 2011, Democracy index 2011. Democracy under stress, http://www.eiu.com/public/topical_report.aspx?camp aignid=DemocracyIndex2011. Adgang 4. august 2014.

Elster, J. 1998, Deliberative Democracy, Cambridge: Cambridge University Press.

Eurobarometer 2012, Standard Eurobarometer 78: First Results, http:// ec.europa.eu/public_opinion/archives/ebleb78_first_en.pdf.

Eurofound, 2012, http://www.eurfopund.europa.eu/surveys/smt/3eqls/ index/EF.php.

Fishkin, J. 1997, The Voice of the People: Public Opinion and Democracy, New Haven: Yale University Press.

Goodin, R.E. 2008, Innovating Democracy: Democratic Theory and Practice after the Innovative Turn, Oxford: Oxford University Press.

Green-Pedersen, C. 2011, Partier i nye tider. Den politiske dagsorden $i$ Danmark, Aarhus: Aarhus Universitetsforlag.

Hansen, B. m.fl. 2013, DeltagerDanmark, København: Informations Forlag.

Hansen, M.H. 2010, Demokrati som styreform og som ideologi, København: Museum Tusculanums Forlag.

Højlund, N. 1993, Folkeafstemninger - en trussel mod demokratiet, København: Gyldendal.

Haarder, B. 1996, 'Demokrati er ikke samtale', i Demokrati. 40 indlag, red. af Søren Bald m.fl., Humlebæk: Krogerup Højskole.

Husted, E.K. 2013, At stemme legitimerer (af)magten', Modkraft 13. nov., Modkraft http://modkraft.dk/artikel/stemme-legitimererafmagten.

Kaspersen L.B. 2008, Danmark i verden. København: Hans Reitzel.

Knudsen, T. 2007, Fra folkestyre til markedsdemokrati. Dansk demokratihistorie efter 1973, København: Akademisk Forlag.

Koch, H. 1981[1945], Hvad er demokrati?, København: Gyldendal.

Kosiara-Pedersen, K. og K. Møller Hansen 2012, Danske partimedlemmer 2012. Dokumentationsrapport fra projektet Moderne Partimedlemskab, København: Center for Valg and Partier, Institut for Statskundskab, Københavns Universitet.

Kurrild-Klitgaard, P. 2008, 'Folkets vetoret skal udvides', Berlingske Tidende, 26. juli.

Københavns Kommune, Notat fra Københavns Kommune af 5. februar 2003 til Strukturkommissionens sekretariat.

Lykkeberg, R. 2013, 'Sjove kulturfolk forsøger at få det kommunale demokrati til at se godt ud', politiken.dk 17. nov., http://politiken. $\mathrm{dk} /$ debat/profiler/runelykkeberg/ECE2134141/sjove-kulturfolkforsoeger-at-faa-det-kommunale-demokrati-til-at-se-godt-ud/

MacLean, I. 1989, Democracy and New Technology, Cambridge: Polity.

Magasinet Politik, 29. maj 2013, http://magasinetpolitik.dk/sass-larsen-demokratisering-er-en-dodssejler/

Mayne, Q 2010, The Satisfied Citizen: Participation, Influence, and Public Perceptions of Democratic Performance, PhD dissertation, Princeton University.

Mill, J.S. 1958 [1861], Considerations on Representative Government, New York: Liberal Arts Press.

Møller Hansen, K. 2007, 'De oplyste danskere: Hvad ved danskerne om politik, og gør det en forskel?', i Jørgen Goul Andersen m.fl. (red.), Det nye politiske landskab. Folketingsvalget 2005 i perspektiv, København: Academica.

Münkler, H. 2011, 'Democratization Can't Save Europe: The Need for a Centralization of Power', Spiegel Online International, 8. juli. http://www.spiegel.de/international/europe/democratization-cant-save-europe-the-need-for-a-centralization-of-power-a-773071. html. Adgang 5. august 2014.

Norris, P. 1999, Critical Citizens: Global Support for Democratic Governance, Oxford: Oxford University Press.

Norris, P. 2011, Democratic Deficit: Critical Citizens Revisited, Cambridge: Cambridge University Press.

OAS Inter-American Democratic Charter 2001.

Olsen, J.P. 2014, Folkestyrets varige spenninger. Stortinget og den norske politiske selvforståelsen, Oslo: Universitetsforlaget.

Pedersen, O.K. 2011, Konkurrencestaten, København: Hans Reitzels Forlag.

Pettit, P. 2001, 'Deliberative Democracy and the Case for Depoliticising Government', University of New South Wales Law Journal, vol. 58, http://www.austlii.edu.au/au/journals/UNSWLJ/2001/58. html\#Heading 83

Qvortrup, M.H. 2013, 'Bespoke Democracy: Direct Political Participation for the Consumer Age?", i Michael Böss, Jørgen Møller og Svend-Erik Skaaning (red.) Developing Democracies: Democracy, Democratizatin, and Development, Aarhus: Aarhus Universitetsforlag.

Runciman, D. 2013, The Confidence Trap: A History of Democracy in Crisis from World War I to the Present, Princeton and Oxford: Princeton University Press.

Strømsnes, K. 2003, Folkets makt. Medborgerskap, demokrati og deltakelse, Oslo: Gyldendal Akademisk.

Stubager m.fl. 2013, Danske vælgere 1971-2011. En oversigt over udviklingen i vælgernes holdninger mv. Det danske valgprojekt, 2 . udgave, februar 2013, http://www.valgprojektet.dk/files/Danske\%20 v\%C3\%A6lgere\%201971-2011\%20-\%20Februar\%202013.pdf.

Svensson, P. 2011, 'Demokratiets legitimitet', i Peter Gundlach (red.), Små og store forandringer. Danskernes vardier siden 1981 , København: Hans Reitzel.

United Nations 2004, Technocratic Policy Making and Democratic Accountability, UNRISD Research and Policy Brief 3, http://www. unrisd.org/80256B3C005BCCF9/(httpAuxPages)/AE49CC52BE FC658EC1256EFA002D44FB/\$file/RPB3e.pdf. Adgang 4. august 2014, Universal Declaration of Human Rights 1948.

Van Reybrouck, D. 2015, Imod valg-til forsvar for demokratiet, København: Tiderne Skifter.

Warren, M.E. og H. Pearse (red.) 2008, Designing Deliberative Democracy, Cambridge: Cambridge University Press.

Warren, M.E. 2009, 'Citizen Participation and Democratic Deficits: Considerations from the Perspective of Democratic Theory', i . DeBardeleben og J.H. Pammet (red.), Activating the Citizen: Dilemmas of Participation in Europe and Canada, Houndmills, Basingstoke: Palgrave.

World Values Survey 2005-2008.

Østerud, Ø,F. Engelstad og P. Selle 2003, Makten og demokratiet. En sluttbok fra Makt-og demokratiutredningen, Oslo: Gyldendal.

\section{Noter}

1. F.eks. Universal Declaration of Human Rights (1948); International Covenant on Civil and Political Rights (1966/1976); American Convention on Human Rights (1969); African Charter on Human and Peoples Rights (1981): Organization of American States's (OAS) Inter-American Democratic Charter (2001); Document of the Copenhagen Meeting of the Conference on the Human Dimension of the Conference on Security and Co-operation in Europe (1990), CSCE Chater of Paris for a New Europe (1991).

2. Danmark deltager ikke i World Values Survey. 